тривку життєву основу музики композитора у житомирський період його творчості і в подальшому.

\title{
Література:
}

1. В.С. Косенко у спогадах сучасників / упоряд.: А.В. Косенко. Київ : Музична Україна, 1967. 179 с.

2. В.С. Косенко. Спогади. Листи. Вид. 2-ге, доп. / упоряд. А.В. Косенко. Київ: Музична Україна, 1975. 295 с.

3. Гордійчук М. Українська радянська симфонічна музика. Київ, 1969. $304 \mathrm{c}$.

4. Довженко В. В. С. Косенко. Київ : Мистецтво, 1951. 125 с.

5. Довженко В. В.С. Косенко: нарис. Київ : Мистецтво, 1949. 140 с.

6. Довженко В. Героїчна увертюра В.Косенка. Київ : Мистецтво, 1963. $29 \mathrm{c}$.

DOI https://doi.org/10.30525/978-9934-26-004-9-5

\section{ПРАВОСЛАВИЕ - «ГЕНЕТИЧЕСКОЕ ЯДРО» РУССКОЙ КУЛЬТУРЫ}

\author{
Дубровская Г. Н. \\ кандидат искусствоведения, \\ дочент кафедры общего и специиализированного фортепиано \\ Одесской национальной музыкальной академии \\ имени А. В. Неждановой \\ 2. Одесса, Украина
}

1. Понятие «культура» многозначно, вмещающее духовнонравственные, религиозные и творческие аспекты: «образование умственное и нравственное, предполагающее и элементы творческие» (В. Даль) $[2,78]$; «творится не сознанием, не рассудком и не произволом, а целостным, длительным и вдохновенным напряжением всего человеческого существа, отыскивающего прекрасную форму для глубокого содержания; прежде всего, инстинктом... Вера есть духовный язык инстинкта» (И. Ильин) [4, с. 17].

2. Культура соотносима с культом: «возделывание», соотносимое с «земледелием», то есть истоками, почвой, корнями, произрастающими из культа (cultura от cultus)... Святыни - первичное творчество человека; культурные ценности - производные культа» (П. Флоренский) 
[14, с. 117]; «в основе всего - культ», вокруг него «как плотное облако, помещена культурная среда, в которой нерасчлененно присутствует язык, музыка, танец, архитектура... эти культурные формы обосабливаются и начинают жить самостоятельно, все еще сохраняя связь с культовым ядром. Если эта связь со временем порвется, то оторвавшаяся форма культуры замыкается на самой себе, какое-то время живет по инерции, затем приходит к самоотрицанию» (прот. Андрей (Ткачев) [13, с. 35].

3.Русская культура - часть многонациональной Православной культуры, с общими историческими, ментальными и религиозными источниками: «русская вера сложилась из взаимодействия трех сил: греческой веры..., славянского язычества... и русского народного характера» (о. Павел Флоренский) [14, с. 150]; Русью «усваивается некая «Квинтэссенция» православного византинизма, русское сознание включается в эту традицию, и она станет основоположным источником русской культуры» (прот. Александр Шмеман) [16, с. 355], добавим - и музыкальной культуры. Отпочковавшееся от культа светское искусство отражает и запечатлевает окружающий мир, пользуясь, «речью, моторикой и игрой» - «тремя прототипами музыкальной логики» (Е. Назайкинский) [9, с. 228].

4.Связь с Богом, «слышание душою Бога» различно в западном и восточном мировосприятии. Искусство зодчества храмов отражает «внутреннюю тайну» строящего народа - «религиозного восприятия душой Бога». «Западные народы восприняли тайну христианства хотя и сильно, но... внешне, извне... опыт Галилейских полей и цветущих лилий (Франциск Ассизский и другие) и движение за Христом по плоскости этих полей (Крестовые походы)... в зодчестве восточных храмов «небо от земли неотделимо». Православный «стиль» обращается к внутреннему миру. Восточное монашество - «детище древних народов», в нем «опыт созерцания «конца» в понимании его и как конца «тленного, грешного бытия» и конечной «судьбы всего мира» (прот. Иоанн (Журавский) [3, с. 19-20]; «поздняя готика связана с идеологией нищенствующих орденов, с францисканством, «византийское и русское предвозрождение... с исихазмом» (Д. Лихачев) [6, с. 123]. В католических храмах впечатляет внешняя сторона: фресково-живописные отображения евангельских событий, скульптуры, «доступность» алтаря, краткость месс, «приспособленность» под концертные залы, участие музыкальных инструментов (орган), музыка - более страстная, душевная. «Разве непосредственно не явно, что звуки инструментальной музыки, даже звуки органа, как таковые, т. е. назависимо от композиции музыкального 
произведения, непереносны в православном богослужении. Это дано непосредственно на вкус... не вяжется в сознании со всем богослужебным стилем, нарушает замкнутое единство богослужения, даже рассматриваемого как просто явление искусства или синтеза искусств» (о.Павел Флоренский) [14, с. 105].

5. В западной культуре доминирует авторство. Древнерусские писатели «не зодчие отдельно стоящих зданий, это - градостроители». Они работали над «общим грандиозным ансамблем». В древнерусском искусстве важнее школы, церковная музыка надындивидуальна, плод коллективного творчества, без «категории индивидуального стиля» (акад. Д. Лихачев) [5, с. 57], с приглушенным авторским началом, подобно древнерусской литературе: «В ней не было ни Шекспира, ни Данте. Это хор, в котором господствует унисон»...; в древнерусской живописи: «мы знаем имена Рублева, Феофана Грека, Дионисия и его сыновей. Но и их искусство прежде всего искусство традиции и лишь во вторую очередь - искусство индивидуальной творческой инициативы» [5, с. 10-11]; и иконописи: «Икона, даже первообразная, никогда не мыслилась произведением уединенного творчества, она существенно принадлежит соборному делу Церкви. И даже если по тем или иным причинам икона от начала до конца написана одним мастером, то какоето идеальное соучастие в ее написании других мастеров подразумевалось... Ведь отсутствие соучастников требуется ради единства индивидуальной манеры, а в иконе - главное дело в незамутненности соборно передаваемой истины» (о.Павел Флоренский) [15, с. 159-160]; «обезличенность» авторства являла мудрость и глубину, предполагая смиренность, несамовозвеличание, не гордыню.

6. Всякое явление действительности «всегда имеет духовный смысл, символизирует этот смысл» [11, с. 324]. Храм - «микрокосмос», совмещающий черты символического христианского строения мира и человека, в православных храмах связанная с Таинствами: форма храма в виде корабля; иконостас - символ границы между Небом и землей, придающий сакральность, таинственность богослужебному действу; иконы - «окна в горній мир»; клирос с пением хора - символ ангельского славословия и сама музыка, исполняемая а capella, непосредственно воспевающая молитвы к Богу. Храмовое действо - целостный организм, синтез искусств: основных (иконопись, фресковое, храмово-вокальной речитации, псалмодии) и вспомогательных («искусство огня», «искусство дыма», «искусство одежды» - «уединяющие оболочки, как форма сферы, наполненной деятельностями»; своеобразной хореографии, проступающей в размеренности церковных движений а 
также тактильное искусство (прикосновение губами к иконам, «искусство осязания», «искусство обоняния», «устраняя их, мы лишились бы полноты и завершенности художественного целого» [14, с. 219, 229] и синкрезис зодчества: просторные нефы, купола, неповторимая храмовая акустика, колокольня, и сам колокольный звон, принадлежащий сфере ритуально-музыкальной.

7. Контрастны католические и православные заупокойные службы: латинский Requiem, «с атмосферой надвигающейся тревоги, ритмом надвигающейся грозы, главенствующей темой Конца Света и Страшного Суда, на котором «и праведный едва оправдается», и православное отпевание, утверждающее «своих участников в чувстве удивительного покоя» (Седакова) [12, с. 60-61]. Православная литургия первоначально подразумевала не только богослужение, но и служение ближним (Рим. 15, 26-27; Евр. 9, 12; Фил. 2, 30), будучи 1. благодарением за сотворение мира «из ничего» [1, с. 103], 2. знаком «эсхатологического Спасения, причастником которого человек становится благодаря Христу» [1, с. 110]; «человек, живя в мире, думал о мире в целом... Церковь была микромиром, и вместе с тем, она была макрочеловеком... Большой мир и малый, Вселенная и человек! Все взаимосвязано, все значительно, все напоминает человеку о смысле его существования, о величии мира и значительности в нем судьбы человека» (Д. Лихачев) [5, с. 10]. Это отражалось во внешней стороне символического действа литургической драматургии («богословии движений» - символика Малого и Большого входов, движения по и против часовой стрелки, совершающего каждение священника, по форме напоминающего знак бесконечности $\omega$ и прочее, ритмика, согласующая темп богослужебных действий с темпом музыки, их сопровождающей) - неведомой, невидимой жизни, связывающей человека с «иными мирами» и постигаемой через Таинства... синергизм «созвучие энергий, соцветие сил, сливающихся в истине, красоте и любви» (В. Медушевский) [8, с. 56].

8. Русская культура неотрывна от Православия, изначально воспреемница греческой традиции; русский человек рождался и умирал под «образами», в храме его крестили, венчали и отпевали, но главное русский народ искренне веровал во Христа, это было частью жизни, а следовательно и культуры, им создаваемой: «вносить свет Христова учения в земную жизнь и творчески раскрывать дары Святого Духа в ее ткани - значит создавать христианскую культуру на земле» (И. Ильин) $[4$, c. 18$]$.

9. В процессе изменения жизни религия и искусство, сначала связанные с культом, затем все более отдаляясь, получало независимые и 
самостоятельные формы, иную смысловую нагрузку. «Истинное «реалистическое искусство создает символы вещей, тогда как мнимое искусство - их иллюзорные подобия» (С. Осадчая) [10, с. 231]. Что касается музыкантов, композиторов, то многие из них параллельно работали как в светской, так и церковной сфере, служа регентами в Православных храмах. Композиторы-медиевисты С. Смоленский. А.Кастальский, П.Чесноков и др., стремились возродить древнерусскую певческую культуру на основе западно-европейских традиций с учетом особенностей русской подголосочной полифонии и знаменного роспева. С. И. Танеев полагал «укоренение профессионального творчества на национальной основе путем создания «православной кантаты» (Г.Лукина) [7, с. 64-65].

10.Православие «жило» и в атеистические времена гонений в СССР в живописи, литературе, музыке (муж легендарной А.В. Неждановой, главный дирижер ГАБТ, Николай Голованов служил регентом Собора в Москве и писал духовные сочинения), иной раз в иносказательном виде. Живет и ныне.

\section{Литература:}

1. Георгий (Вагнер), архиеп. Происхождение Литургии Иоанна Златоуста. «Liturgica». -12 rue Daru. - 78008. -Paris, 1995.- 170 с.

2. Даль В. Толковый словарь живого великорусского языка в 4 т. М.: РИПОЛ КЛАССИК, 2002. - Т. 2.- 782 с., т. 4. - 672 с.

3. Журавский И., прот. Тайны Царствия Божия. - СПб: Царское дело, 2001. - 287 с.

4. Ильин И. Основы христианской культуры - СПб: Изд-во «Шпиль», 2004. - 351 с.

5. Лихачев Д. Великое наследие: Классические произведения литературы Древней Руси. - М.: Современник, 1980. - 412 с.

6. Лихачев Д. Поэтика древнерусской литературы. - М. : Наука, 1979. $-352 \mathrm{c}$.

7. Лукина Г. Творчество С.И.Танеева в свете русской духовной традиции. Монография. - М. : Издательство Композитор, 2015. 364 с. : илл.

8. Медушевский В. Внемлите ангельскому пенью. Человечество и его культура на пороге 2000-летия Рождества Христова (по страницам трудов профессора В. В. Медушевского) / Сост. О.А. Галкин.- Мн.: Православное братство во имя Архистратига Михаила, 1999. 320 с. : илл. 
9. Назайкинский Е. Логика музыкальной композиции. - М.: Музыка, 1982. $-319 \mathrm{c}$.

10. Осадчая С. Цикличность как ключевое свойство функционирования богослужебно-певческой традиции / Муз. мистецтво i культура. Вип. 23. - Одесса, 2016. - С. 228-237.

11. Русские мыслители. Ростов н /Д: «Феникс», 2003. - 352 с.

12. Седакова О. Вечная память. Литургическое богословие смерти. Памяти Сергея Сергеевича Аверинцева // P.:Le Messager. - Paris, 2004. Вестник русского христианского движения. № 188, 2004. - С. 52-71.

13. Ткачев А., прот. Под скальпелем природы и искусства. Православный журнал для молодежи «Отрок». - К.: «Держава»-2005.№ 5 . - С. 35 .

14. Флоренский П. Вопросы религиозного самопознания «Храмовое действо как синтез искусств»- М.: Изд-во «Москва», 2004. - 236 с.

15. Флоренский П. Иконостас - М.: Москва. - 2005. - 204 с.

16. Шмеман Александр, протоиерей. Исторический путь Православия.- М.: «Паломник», 2007. - 400 с.

DOI https://doi.org/10.30525/978-9934-26-004-9-6

\title{
МОДА ЯК СОЦІОКУЛЬТУРНИЙ ТА СЕМІОТИЧНИЙ ФЕНОМЕН
}

\author{
Калініна О. С. \\ кандидат культурологіï, \\ старший викладач кафедри культурологічних дисциплін \\ та образотворчого мистеитва \\ Харківської гуманітарно-педагогічної академії \\ м. Харків, Украӥна
}

Мода - реальний і діючий факт нашого соціального життя, що впливає на багато аспектів життєдіяльності людини і суспільства. Інтерес до здатності моди відображати специфіку суспільних трансформацій, що відбуваються стає основою побудови теоретичної системи знань про нього. Мода як науковий факт характеризує соціальні процеси, які знаходять своє виявлення у зовнішніх формах культури, модних значеннях, що вказують на цінності моди, якими наділяються ті чи інші властивості об'єктів і подій. Моді, за визначенням, властива тенденція до постійного руху та інновацій, тому вона завжди показує актуальний в певний період суспільний i культурний зміст, сутність якого 